\title{
Effectiveness of Giving Red Ginger Extract in Preventing Damage to B-Pancreatic Cells in Wistar Strain White Rats (Rattus Norvegicus)
}

\author{
Wiwiek Wira $^{1^{*}} \quad$ Bambang Wirjatmadi $^{2} \quad$ Merryana Adriani $^{2}$ \\ 1.Master's Program, Department of Public Health, Faculty of Public Health, Universitas Airlangga, Indonesia \\ 2.Faculty of Public Health, Universitas Airlangga, Indonesia
}

\begin{abstract}
Background: One of the goals of therapy for diabetes mellitus is to maintain normal glucose levels. Therapy can be in the form of pharmacology and non-pharmacology. In addition, in the community many use traditional medicine or often known as herbal medicine for the treatment of diabetes. Traditional medicine that has many uses for treatment is ginger. The main ingredients of ginger are essential oils (1-5\%), sesquiterpenoids and monoterpenoids, gingerols, shogaols, paradols and zingerones. The effects of ginger therapy are antiinflammatory, analgesic, hypotensive and diabetic which is associated with gingerol and shogaol which are abundant in fresh ginger and ginger.

Objectives: The aim of the study was to analyze the effectiveness of red ginger extract in preventing damage to ß-pancreatic cells in wistar strain white rats (rattus norvegicus)

Methods: This study was laboratory experimental study with randomized post-test only control group design. The independent variable was the administration of red ginger extract, the dependent variable was blood sugar levels and the control variables were rat type, rat sex, rat age, rat body weight and rat health. The samples were 25 male Wistar strain white rats aged 8-12 weeks. The samples were divided into 5 groups randomly. One group not induced by diabetes was the healthy control group (K1). The other four groups were induced by diabetes: (K2) control of diabetes; (K3) given $500 \mathrm{mg} / \mathrm{kgBW}$ of red ginger extract; (K4) given $750 \mathrm{mg} / \mathrm{kgBW}$ of red ginger extract and (K5) given $1,000 \mathrm{mg} / \mathrm{kgBW}$ of red ginger extract. ANOVA test with $\alpha=0.05$ was used to determine the effect of treatment. Furthermore, an effect size test analysis was conducted to determine the effectiveness of red ginger extract

Results: all of the treatment $(500 \mathrm{mg} / \mathrm{kgBW}, 750 \mathrm{mg} / \mathrm{kgBW}$ and $1,000 \mathrm{mg} / \mathrm{kgBW}$ of red ginger extract) had strong effect on fasting blood sugar control of the mice (effec size> 1)

Conclusions: the treatment where $750 \mathrm{mg} / \mathrm{kgBW}$ of red ginger extract was administered has the highest value of effectiveness $(3,632)$, while that in which $1,000 \mathrm{mg} / \mathrm{kgBB}$ of red ginger extract was administered has the lowest value of effectiveness $(1,195)$.
\end{abstract}

Keywords: Effectiveness, red ginger, ß-pancreatic cells

DOI: $10.7176 / \mathrm{JMPB} / 55-01$

Publication date:May $31^{\text {st }} 2019$

\section{INTRODUCTION}

Diabetes is one of the major health treats for human being in the $21^{\text {st }}$ century. World Health Organization (WHO) predicted that in 2000 number of 20-year-old individuals with diabetes are 150 millions and in 2025 the number will multiply to 300 million people ${ }^{1}$. Type II diabetes is a more commonly-found type of diabetes; $90-95 \%$ of diabetes patients suffer from this type of diabetes ${ }^{1}$.

Diabetes mellitus is influenced by two factors, genetic factor and environment. Type 2 Diabetes Mellitus can be interpreted as metabolic disorder characterized by increase of blood sugar due to decreasing insulin secretion in the pancreas ${ }^{2}$. Type 2 diabetes occurs when insulin production in beta pancreatic cells is decreasing or due to secretion failure, and as the result glucose cannot insert the tissue ${ }^{3}$, causing insulin retention which results in decrease of insulin leading to inability to secrete glucose well. As the result, the pancreas will reduce response for insulin secretion ${ }^{3}$.

Diabetes mellitus therapy aims to achieve normal glucose level, decrease the onset and development of retinopathy, complications of nephropathy and neuropathy, intensive therapy for associated cardiovascular risk factors, and improve quality and quantity of life ${ }^{4}$. Therapy can be in the form of pharmacological and nonpharmacological. In addition these types of therapies, traditional medicine (herbs) is an alternative treatment people use for diabetes mellitus ${ }^{5}$. Type of herbs used to treat diabetes mellitus is ginger 6 . The main ingredients of ginger are essential oils (1-5\%), sesquiterpenoids and monoterpenoids, gingerols, shogaols, paradols and zingerones ${ }^{7}$. Ginger is mainly used as anti-inflammatory, analgesic, hypotensive and for diabetes related to gingerol and shogaol which are widely found in fresh and dried ginger ${ }^{7}$.

Clinical studies show that consuming 3 grams of powdered ginger everyday for 30 days can reduce blood sugar, triglyceride, total cholesterol, LDL and VLDL in the blood ${ }^{8}$. However, consuming 2 grams of ginger 
everyday for 8 weeks did not have significant influence in decreasing fasting blood sugar, $\mathrm{HbA} 1 \mathrm{C}$, or $\mathrm{HDL}^{9}$. As an addition, administering ginger for osteoarthritis patients can reduce pain but cannot reduce $\operatorname{stiffness}^{10}$. Objective of this study is to analyze effectiveness of red ginger extract in preventing ß-pancreatic cell damage in Wistar strain white mice (rattus norvegicus)

\section{METHODOLOGY}

This study was an experimental laboratory with randomized post test only control group design and was conducted for 4 weeks in the laboratory of Faculty of Animal Science Universitas Airlangga Surabaya. The independent variable was administration of red ginger extract in various dosage, the dependent variable of was blood sugar levels and the control variables of were rat type, sex, age, body weight and health.

The samples were 25 male Wistar strain white mice (Rattus norvegicus) aged 8 to 12 weeks and weighed $\pm 150-200$ grams. During this study, the mice were fed 20 grams of standardized pellet (20 grams/mouse/day) and distilled water ad libitum. Induction of diabetes was conducted through saline-distilled intraperitoneal alloxan monohydrate $(160 \mathrm{mg} / \mathrm{kgBW})$. Hyperglicemic confirmation was conducted 5 days after induction by examining the mice's blood sugar level; prior to the examination, the samples were not fed for 12 hours.

The samples were divided into 5 groups randomly. One group was not induced by diabetes (healthy control group or K1). The other four groups were induced by diabetes: (K2) control of diabetes; (K3) given 500 $\mathrm{mg} / \mathrm{kgBW}$ of red ginger extract $500 \mathrm{mg} / \mathrm{kgBW}$; (K4) given $750 \mathrm{mg} / \mathrm{kgBW}$ of red ginger extract $750 \mathrm{mg} / \mathrm{kgBW}$ and (K5) given $1,000 \mathrm{mg} / \mathrm{kgBW}$ of red ginger extract. The treatment lasted for 15 days and the samples were fed with red ginger extract using gastric tube.

This study was conducted at the Laboratory of the Faculty of Veterinary Medicine, Universitas Airlangga in January 2019. The blood sugar level examination was conducted by taking blood samples from veins of the mice with Dr-Glucose devices and strips.

Data analysis methods were descriptive and inferential analyses that measure influence of the treatment using one-way ANOVA with 95\% level of confidence. Effect size test was conducted towards the five groups of samples to identify effectiveness of red ginger extract.

\section{FINDINGS AND DISCUSSION}

Based on findings of this study, the researchers were able to analyze blood sugar level of the Wistar strain white mice (Rattus norvegicus) prior to and after the treatment for 20 days. Data were obtained based on examination towards each group of samples (type of treatment, repetition and dosage administered). One-way ANOVA was used for hypothesis testing, yet requirement for the statistical analysis was normally distributed and homogenous data. Based on the analysis, data obtained prior to (pre) and after (post) the treatment had normal distribution where significance $(p)$ was $0.200(\mathrm{p}>0.05)$. Furthermore, the variance homogeinity test showed that significance of blood sugar level pre-treatment was $0.114(\mathrm{p}>0.05)$ and significance of blood sugar level post treatment was $0.122(\mathrm{p}>0.05)$. Thus, it can be concluded that data showing blood sugar level prior to (pre-) and after (post-) treatment were homogenous. As the result, hypothesis testing with ANOVA can be conducted.

Comparison between fasting blood sugar level of mice given $500 \mathrm{mg} / \mathrm{kg} \mathrm{BW}, 750 \mathrm{mg} / \mathrm{kg} \mathrm{BW}$ and 1,000 $\mathrm{mg} / \mathrm{kg} \mathrm{BW}$ of red ginger extract, fasting blood sugar level of the healthy control group and fasting blood sugar level of the diabetic control group showed that, pre-treatment, $\mathrm{K} 3$, where mice were given $500 \mathrm{mg} / \mathrm{kgBW}$ of red ginger extract, had the highest blood sugar level $(99.6 \mathrm{mg} / \mathrm{dl})$ while $\mathrm{K} 2$ (diabetic control group) had the lowest $(90 \mathrm{mg} / \mathrm{dl})$. At the end of the study, dosage of red ginger extract influenced average blood sugar level of the mice. The higher the dosage is, the lower the blood sugar level is. Figure 1 describes average blood sugar level of the five groups of mice prior to and post treatments. 


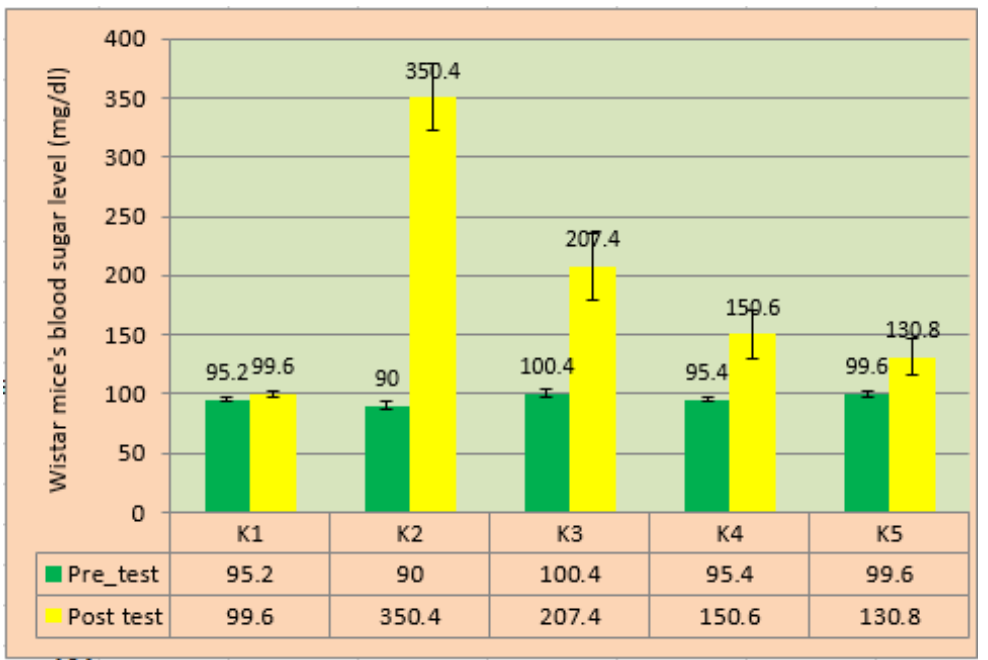

Figure 1 Average Blood sugar Level of K1, K2, K3, K4 and K5 Mice Prior to and Post Treatments

ANOVA, statistical analysis, with 5\% level of significance showed that there was significance difference in blood sugar level between three groups of the Wistar mice, in which $p$ or significance was $0.000(p<0.05)$. At the end of the treatments, $500 \mathrm{mg} / \mathrm{kg} \mathrm{BW}, 750 \mathrm{mg} / \mathrm{kg} \mathrm{BW}$, and 1,000 mg/kg BW had influence towards controlling average hyperglycemic blood sugar level of the white rats (Rattus norvegicus). The significance at the end of the treatments was $\mathrm{p}=0.000(\mathrm{p}<0.05)$. Table 1 showed average blood sugar level of the white mice pre- and post-treatment.

Table 1 Average Blood Sugar Level of the Control Group and the Experiment Groups Prior to and After the Treatments

\begin{tabular}{|c|c|c|c|c|c|c|}
\hline \multirow{2}{*}{ Treatment } & \multicolumn{5}{|c|}{ Fasting Blood sugar Level } \\
\cline { 2 - 6 } & \multicolumn{2}{|c|}{ Pre-Treatment } & \multicolumn{2}{c|}{ Post Treatment } \\
\cline { 2 - 7 } & Mean \pm SD & Min & Max & Mean \pm SD & Min & Max \\
\hline K1 & $95.2 \pm 1.48^{\mathrm{b}}$ & 93 & 97 & $99.6 \pm 2.61^{\mathrm{a}}$ & 96 & 102 \\
K2 & $90.0 \pm 3.67^{\mathrm{a}}$ & 86 & 95 & $350.4 \pm 28.26^{\mathrm{d}}$ & 321 & 379 \\
K3 & $100.4 \pm 3.58^{\mathrm{c}}$ & 95 & 104 & $207.4 \pm 27.92^{\mathrm{c}}$ & 178 & 253 \\
K4 & $95.4 \pm 1.52^{\mathrm{b}, \mathrm{c}}$ & 93 & 97 & $150.6 \pm 20.27^{\mathrm{b}}$ & 124 & 180 \\
K5 & $94.4 \pm 2.61^{\mathrm{b}, \mathrm{c}}$ & 97 & 103 & $130.8 \pm 15.32^{\mathrm{a}, \mathrm{b}}$ & 112 & 154 \\
\hline Ket & \multicolumn{2}{|c|}{$\mathrm{p}=0.000(\mathrm{p}<0.05)$} & \multicolumn{2}{c}{$\mathrm{p}=0.000(\mathrm{p}<0.05)$} \\
\hline
\end{tabular}

Description:

Different superscript ${ }^{(\mathrm{a}, \mathrm{b}, \mathrm{c}, \mathrm{d})}$ on the same column showed significant difference $(\mathrm{p}<0.05)$.

K1 : Healthy Control Group

K2 : Diabetic Control Group

$\mathrm{K} 3: 500 \mathrm{mg} / \mathrm{kgBW}$ of red ginger extract treatment

$\mathrm{K} 4: 750 \mathrm{mg} / \mathrm{kgBW}$ of red ginger extract treatment

$\mathrm{K} 5: 1,000 \mathrm{mg} / \mathrm{kgBW}$ of red ginger extract treatment

Comparison between fasting blood sugar level of K3 mice, mice given $500 \mathrm{mg} / \mathrm{kg} \mathrm{BW}$ of red ginger extract for 15 days and then injected with diabetes with $160 \mathrm{mg} / \mathrm{kg} \mathrm{BW}$ of saline-dissolved intraperitoneal alloxan monohydrate on day 16 to 20, fasting blood sugar level of healthy control mice (K1) and that of diabetic control mice (K2) showed that at the beginning of the treatment average blood sugar level of K2 (diabetic control group) is $90 \mathrm{mg} / \mathrm{dl}$, slightly lower than $\mathrm{K} 1$ (healthy control group) of which blood sugar level was $95.2 \mathrm{mg} / \mathrm{dl}$ and $\mathrm{K} 3$ (mice given $500 \mathrm{mg} / \mathrm{kg} \mathrm{BW}$ of red ginger extract) of which blood sugar level was $100.4 \mathrm{mg} / \mathrm{dl}$. However, at the end of the treatments, blood sugar level increased sharply to $350.4 \mathrm{mg} / \mathrm{dl}$ (hyperglicemic), whereas blood sugar level of K3 mice can be maintained to $207.4 \mathrm{mg} / \mathrm{dl}$ (non-hypreglicemic).

This study shows that the treatments (various dosage of red ginger extract) can significantly reduce average blood sugar level of mice with diabetes so that average blood sugar level of these mice is similar to that of the control (healthy mice). Previous studies explained that red ginger has abundant health benefits. In in-vitro studies, ginger extract can increase insulin release in $\beta$ - pancreatic cells of mice ${ }^{11}$. Furthermore, glucose tolerance test confirmed that this ginger extract also increases plasma insulin level decreasing blood sugar level ${ }^{12}$.

Comparison between blood sugar level of mice given $750 \mathrm{mg} / \mathrm{kg}$ bW of red ginger extract for 15 days and then injected with diabetes with $160 \mathrm{mg} / \mathrm{kg} \mathrm{BW}$ of saline-dissolved intraperitoneal alloxan monohydrate, blood sugar level of healthy mice (K1) and that of K2 showed that at the beginning of the treatment average blood sugar level of $\mathrm{K} 1$ is $95.2 \mathrm{mg} / \mathrm{dl}$ or similar to average blood sugar level of K4 (mice given $750 \mathrm{mg} / \mathrm{kg} \mathrm{BW}$ of red 
ginger extract) which is $95.4 \mathrm{mg} / \mathrm{dl}$. The average blood sugar level of $\mathrm{K} 1$ is slightly higher compared to $\mathrm{K} 2$ of which blood sugar level is $90.0 \mathrm{mg} / \mathrm{dl}$. As an addition, at the end of the treatment, average blood sugar level of K4 mice (mice given $750 \mathrm{mg} / \mathrm{kg} \mathrm{BW}$ of red ginger extract for 15 days and injected with aloxan for 5 days) increased to $150.6 \mathrm{mg} / \mathrm{dl}$, while average blood sugar level of K2 mice jumped to $350.4 \mathrm{mg} / \mathrm{dl}$ (hyperglycemic).

Based on the previous paragraph, red ginger extract can reduce blood sugar level. It is in line with a previous study which concluded that administration of $750 \mathrm{mg} / \mathrm{kg}$ of ginger water extract (dose dependent) in alloxan-induced mice $(150 \mathrm{mg} / \mathrm{kg})$ for 42 days decreases blood sugar level, total serum lipids and total serum cholesterol, through insulin production stimulation that is from islet beta pancreas increasing peripheral use and blocking tubular proximal reabsorption mechanism for glucose in the kidneys ${ }^{13}$.

Comparison between fasting blood sugar level of mice given $1,000 \mathrm{mg} / \mathrm{kg} \mathrm{BW}$ of red ginger extract for 15 days and then injected with diabetes with $160 \mathrm{mg} / \mathrm{kg}$ BW of saline-dissolved intraperitoneal alloxan monohydrate on day 16 to 20, and fasting blood sugar of K1 and K2 mice showed that at the beginning of the treatment average blood sugar level of K5 (diabetic mice given 1,000 mg/kg BW of red ginger extract) was 99.6 $\mathrm{mg} / \mathrm{dl}$, the highest among $\mathrm{K} 2(90 \mathrm{mg} / \mathrm{dl})$ and $\mathrm{K} 1(95.2 \mathrm{mg} / \mathrm{dl})$.

At the end of the treatment, average blood sugar level of $\mathrm{K} 2$ increased sharply to $350.4 \mathrm{mg} / \mathrm{dl}$ (hyperglycemic) and average blood sugar level of K5 (mice given 1,000 mg/kg BW of red ginger extract for 15 days and then induced with alloxan for 5 days) increased slightly to $130.8 \mathrm{mg} / \mathrm{dl}$.

Mustafa, et.al (2012) concluded that 1 and 2 milligrams of ginger water extract on i.p. for 3 weeks are able to decrease blood sugar level of mice through anti-oxidant activity mechanism, mineral content responsible for hypoglycemic activity and a number of essential minerals associated with insulin release mechanism ${ }^{14}$.

The following table explains change of blood sugar level of the Wistar strain white mice prior to and after administration of red ginger extract.

Table 2. Average Ratio of Blood Sugar Level of the Wistar Mice Group Pre and Post Treatment

\begin{tabular}{|c|c|c|c|c|}
\hline \multicolumn{2}{|c|}{ Ratio of Blood Sugar Level Pre and Post Treatment } & \multicolumn{3}{|c|}{ T-test } \\
\hline Group & Mean \pm SD & Group & sig & Ket \\
\hline K3 & $107.00 \pm 29.78$ & K3 and K4 & 0.012 & Significant Difference \\
K4 & $55.20 \pm 20.07$ & K3 and K4 & 0.001 & Significant Difference \\
K5 & $31.20 \pm 15.80$ & K4 and K5 & 0.069 & No Significant Difference \\
\hline
\end{tabular}

Based on Table 2, after the treatment $(500 \mathrm{mg} / \mathrm{kg} \mathrm{BW}$ of red ginger extract and alloxan injection, average blood sugar level of K3 mice increased to $107.00 \pm 29.78 \mathrm{mg} / \mathrm{dl}$. Average blood sugar level of K4 and K5 mice also increased to $55.20 \pm 20.07 \mathrm{mg} / \mathrm{dl}$ and $31.20 \pm 15.80 \mathrm{mg} / \mathrm{dl}$ consecutively after the treatment.

T-test towards K3 and K4 identified significant difference as $\mathrm{p}=0.012(\mathrm{p}<0.05)$. There was significant difference between $\mathrm{K} 3$ and $\mathrm{K} 5$ juga since $\mathrm{p}=0.001(\mathrm{p}<0.05)$. However, there is no significant difference between $\mathrm{K} 4$ and K5 because $\mathrm{p}=0.069(\mathrm{p}>0.05)$. Ginger consists of anti-oxidant such as flavonoid and polyphenols, oxalic acid and vitamin $\mathrm{C}$. These anti-oxidants neutralize damaging effect of free radicals in the body ${ }^{17}$. Table 3 describes result of effect size test towards three groups of treatment (K3, K4 and K5).

Table 3. Average Blood Sugar Level of the Wistar Mice Groups Pre and Post Treatment, and Analysis on Effectiveness of the Treatment

\begin{tabular}{|c|c|c|c|c|c|c|}
\hline \multirow{2}{*}{$\begin{array}{c}\text { Treatment } \\
\text { Group }\end{array}$} & \multicolumn{2}{|c|}{ Pre-Treatment } & \multicolumn{2}{|c|}{ Post Treatment } & \multirow{2}{*}{ Effect Size } & \multirow{2}{*}{ Description } \\
\cline { 2 - 5 } & Mean & SD & Mean & SD & & Strong Effect \\
K3 & 100.40 & 3.58 & 207.4 & 27.92 & 2.989 & Strong Effect \\
K4 & 95.40 & 1.52 & 150.6 & 20.27 & 3.632 & Strong Effect \\
\hline
\end{tabular}

Based on the effect size analysis towards K3 (mice given $500 \mathrm{mg} / \mathrm{kg} \mathrm{BW}$ of red ginger extract), K4 (mice given $750 \mathrm{mg} / \mathrm{kg} \mathrm{BW}$ of red ginger extract) and $\mathrm{K} 5$ (mice given 1,000 mg/kg BW of red ginger extract), red ginger extract had strong effect in controlling fasting blood sugar level of K3, K4 and K5 mice. K4 has the highest effectiveness score (3.632), while K5 has the lowest one (1.195).

Administration of ginger extract for 3 weeks to alloxan-induced mice $(150 \mathrm{mg} / \mathrm{kg})$ can reduce blood sugar level ${ }^{15}$. Suitable dosage of ginger juice is $4 \mathrm{ml} / \mathrm{kg}$. The mechnanism is mineral element ginger contains has hypoglycemic activity and essential minerals $(\mathrm{Ca}, \mathrm{Zn}, \mathrm{K}, \mathrm{Mn}$ and $\mathrm{Cr}$ ) associated to insulin release mechanism. Based on blood sugar examination, ginger extract can cut down Glibenklamid dosage to half when the extract is administered together with Glibenklamid. However 1x dosage of ginger extract does not have similar effect to Glibenklamid, but it has the same effect to $1 / 2 \mathrm{x}$ dosage of Glibenklamid and $1 / 2 \mathrm{x}$ dosage of ginger extract. It means ginger extract will have the same effect to treatment consisting of ginger even though dosage of ginger in the treatment is reduced to $1 / 2 \mathrm{x}$. It happens because ginger extract (Gingerol \& Shogaol) stimulates release of insulin and its effect, as well as improves carbohydrate and fat metabolism. Ginger has protective effect towards complication of liver diabetes, the kidneys, eyes and nerves ${ }^{16}$. Findings of this study also shows ginger extract canb reduce Glibenklamid dosage to half to obtain the same effect as 1x dosage of Glibenklamid. The difference between ginger juice and Glibenclamide lies in the specificity of action of Glibenclamide on beta pancreatic cells 
in the release of insulin compared to compounds contained in the ginger juice which are still mixed with other compounds, which cause unspecified effects ${ }^{16}$.

\section{CONCLUSION}

Administration of $750 \mathrm{mg} / \mathrm{kg} \mathrm{BW}$ of red ginger extract has the highest effectiveness (3.632). It means that 750 $\mathrm{mg} / \mathrm{kg} \mathrm{BW}$ of red ginger extract for 15 days is the most effective dosage to control fasting blood sugar level of the Wistar mice. Administration of $1,000 \mathrm{mg} / \mathrm{kg} \mathrm{BW}$ has the lowest effectiveness (1.195). In other words, 1,000 $\mathrm{mg} / \mathrm{kg} \mathrm{BW}$ for 15 days is the least effective dosage for controlling fasting blood sugar level of the Wistar mice. Based on the findings of the study, an effective dosage of red ginger extract to prevent diabetes mellitus is 750 $\mathrm{mg} / \mathrm{kg} \mathrm{BW}$ as it controls increase of blood sugar. In conclusion, administration of various dosage of red ginger extract can prevent increase average blood sugar level significantly and even return average blood sugar level of mice injected with diabetes to normal blood sugar level.

\section{ACKNOWLEDGEMENT}

The authors would like to send their gratitude to their advisors, faculty members at Master's Program of Public Health Department of Public Health Universitas Airlangga, staffs at the laboratory of Faculty of Veterinary Science Universitas Airlangga and fellow students who helped completion of this research.

\section{REFERENCES}

1. Suyono S. (2006) Diabetes Melitus di Indonesia. Buku ajar Ilmu Penyakit Dalam. IV ed.Jakarta: Pusat penerbitan Ilmu Penyakit Dalam FK UI;

2. Fatimah, Restyana Noor. (2015). Diabetes Melitus Tipe 2. J Majority vol 4 no 5 (101-93)

3. Ndraha S (2014). Diabetes melitus tipe 2 dan tatalaksana terkini. Medicinus, 27 (2): 9-16.

4. Dipiro JT, Talbert RI and Yee GC. Pharmacotherapy: A Pathophysiologic Approach. 7th Ed.Syamford: Appleton \& Lange, 2008.

5. Badan Pengawas Obat dan Makanan (BPOM). (2004). Peraturan Teknis Penggunaan Bahan Tambahan Pangan Pemanis Buatan dalam Produk Pangan. Jakarta: Deputi Bidang Pengawasan Keamanan Pangan dan Bahan Berbahaya.

6. Ali, B.H., G. Blunden, M. O., Tanira, A., Nemmar, 2008, Some phytochemical pharmacological and toxicological properties of ginger (Zingiber officinale Roscoe): A review of recent research,J. Food and Chemical Toxicology,46,409-420.

7. Shukla, Y. and Singh, M., 2007, Cancer Preventive Properties of Ginger : a Brief Review, Food Chem Toxico, 45 (5), 683-690.

8. Andallu, B., Radhika, B., dan Suryakantham, V., 2003. Effect of aswagandha, ginger and mulberry on hyperglycemia and hyperlipidemia. Plant Foods for Human Nutrition, 58: 1-7.

9. Mahluji, S., Attari, V.E., Mobasseri, M., Payahoo, L., Ostadrahimi, A., dan Golzari, S.E.J., 2013. Effects of ginger level, HbA1c and insulin sensitivity in type 2 diabetic patients. International Journal of Food Sciences and Nutrition, 64: 682-686

10. Bachtiar, A. 2010. Pengaruh Ekstrak Jahe (Zingiber Officinale) terhadap Tanda dan Gejala Osteoarthritis pada Pasien Rawat Jalan di Puskesmas Pandanwangi Malang. Depok : Universitas Indonesia

11. Chakraborty A, Mukherjee, Sikdar S, Paul A, Ghosh S. 2012. [6]Gingerol Isolated from Ginger Attenuates Sodium Arsenite Induced Oxidative Stress and Plays a Corrective Role in Improving Insulin Signaling in Mice. Toxicology Letters.210(1):34-43.

12. Priya RM, Padmakumari KP, Sankarikutty B, Lijo CO, Nisha VM, Raghu KG. 2011. Inhibitory potential of ginger extracts against enzymes linked to type 2 diabetes, inflammation and induced oxidative stress. International Journal of Food Sciences and Nutrition. 62(2):106-110.

13. Ozougwu,J.C., Eyo, J.E., 2011, Evaluation of The Activity of Zingiber officinale (Ginger) Aqueous Extracts on Alloxan-Induced Diabetic Rats, Pharmacologyonline 1: 258269

14. Gholib. 2008. Uji Daya Hambat Ekstrak Etanol Jahe Merah (Zingiber officinale var. rubrum) dan Jahe Putih (Zingiber officinale var. amarum) Terhadap Trichophyton mentagrophytes dan Cryptococcus neoformans. Proceeding at National Seminar of Animal Science Technology and Veterinary. Bogor.

15. Elraheem, A., et al., 2009, Effect of Ginger Extract Consumption on levels of blood sugar, Lipid Profile and Kidney Functions in Alloxan Induced-Diabetic Rats. Egypt. Acad. J. biolog. Sci., 2 (1): 153-162.

16. Arnaudon, H. 2002 An International Market Study of Ginger. Micro-Enterprise Development Programme (MEDEP/NEP/97/013) and the District Ginger Entrepreneurs. India.

17. Setyawan, Budi. (2015). Peluang Usaha Budidaya Jahe. Pustaka Baru Press. Yogyakarta. 